Contributors: JD and CP conceived the study. All, in particular $\mathrm{MD}$, developed the methods. MD was responsible for the analysis and producing the maps. JD and CP wrote the article. MD commented critically on the paper. CP revised the paper in the light of reviewers' comments. All authors are guarantors. Funding: None.

Competing interests: None declared.

Ethical approval: Not required.

1 Mori poll for BMA finds many patients willing to travel abroad for treatment. Press release archive, Jun 2002. www.mori.com/polls/2002/bmatravel.shtml (accessed 7 Jan 2005).

2 Department of Health. Performance. 2005. www.dh.gov.uk/PolicyAnd Guidance/Performance/fs/en (accessed 7 Jan 2005).
Laing's healthcare market review 2001-2. London: Laing and Buisson, 2002. Dr Foster good hospital guide 2002. London: Vermilion, Ebury, 2002. Directory of independent hospitals and health services 1998/1999. London: Financial Times Health Care, 1999.

6 National Administrative Codes Service. www.nhs.uk/nacs/ (accessed 7 Jan 2005).

7 MapInfo. www.mapinfo.com (accessed 28 Jan 2005).

8 Mappoint. www.mappoint.com (accessed 7 Jan 2005).

9 Department of Transport. www.dft.gov.uk (accessed 7 Jan 2005)

10 RAC. www.rac.co.uk/ (accessed 7 Jan 2005).

11 Automobile Association. www.theaa.com/ (accessed 7 Jan 2005).

20.

Martin RM, Sterne JAC, Gunnell D, Ibrahim S, Davey Smith G, Frankel S.

NHS waiting lists and evidence of national or local failure: analysis of health service data. BMJ 2003;326:188-98.

(Accepted 15 November 2004)

\title{
Mortality associated with passive smoking in Hong Kong
}

\author{
S M McGhee, S Y Ho, M Schooling, L M Ho, G N Thomas, A J Hedley, K H Mak, R Peto, T H Lam
}

Passive smoking can cause death from lung cancer and coronary heart disease, but there is little evidence for associations with other causes of death in never smokers. A recent study showed increased all cause mortality with exposure to secondhand smoke at home but did not examine associations with specific causes of death and dose-response relations. ${ }^{1}$ We have published estimates of the mortality attributable to active smoking in Hong Kong ${ }^{2}$ and now present the related findings on passive smoking at home.

\section{Participants, methods, and results}

Details of the sample selection and data collection have been reported. ${ }^{2}$ Each person who reported a death in 1998 at four death registries was given a questionnaire which asked about the lifestyle 10 years earlier of the decedent and of a living person about the same age who was well known to the informant. Passive smoking was identified in the interview with the question, "Ten years ago, in about 1988, excluding the decedent/control, how many persons who lived with the decedent/control smoked?" Decedents or controls who lived with one or more smokers were classed as exposed. Cause of death was obtained from the death certificate.

We selected never smoking decedents and controls aged 60 years or over because there were few younger controls. To avoid selection bias, we included only cases and controls who had a living spouse at the time of

\section{What is known on this topic}

There is strong evidence that passive smoking is causally associated with death from lung cancer, coronary heart disease, and all causes, and also with acute stroke

\section{What this study adds}

The dose-response relation between passive smoking and mortality from stroke and chronic obstructive pulmonary disease, as well as from lung cancer, ischaemic heart disease, and all causes of death, strengthens the causal link reporting. We used logistic regression to derive odds ratios adjusted for age and education, and for sex when men and women were combined.

We identified 4838 never smoking cases (55\% male) and 763 never smoking controls ( $55 \%$ male). All controls were used in the analysis for each specific cause of death.

We found significant dose dependent associations between passive smoking and mortality from lung cancer, chronic obstructive pulmonary disease, stroke, ischaemic heart disease, and from all cancers, all respiratory and circulatory diseases, and all causes (table). The association between mortality and passive smoking did not differ between males and females. Deaths due to injury or poisoning were not associated with passive smoking.

\section{Comment}

Dose dependent associations between passive smoking and causes of death are consistent with previous findings for lung cancer and coronary heart disease and extend the evidence on stroke. Previous studies have shown associations between passive smoking and first acute strokes, ${ }^{34}$ and we have now shown a dose-response relation with mortality from stroke. Previous studies focused on ischaemic strokes but Chinese populations have a greater incidence of haemorrhagic stroke than do white populations, ${ }^{5}$ implying that many of the strokes in our study may have been non-ischaemic. Passive smoking probably affects all stroke subtypes, as does active smoking.

Our finding of a $34 \%$ increase in all cause mortality is consistent with but higher than that $(15 \%)$ in the New Zealand cohort. ${ }^{1}$ Exposure to secondhand smoke at home is higher in Hong Kong than in New Zealand due to crowded living conditions. Before the 1990s, awareness of the danger of passive smoking was lower and smokers smoked freely at home.

We focused on passive smoking at home because the proxy reporter could most reliably supply these data, and we adjusted for education, which was also

This article was posted on bmj.com on 27 January 2005: http://bmj.com/ cgi/doi/10.1136/bmj.38342.706748.47
See Editorial by Kawachi

Department of Community Medicine,

University of Hong

Kong, 21 Sassoon

Road, Pokfulam,

Hong Kong, China

S M McGhee

associate professor

S Y Ho

research assistant

professor

M Schooling

research associate

L M Ho

senior computer

manager

G N Thomas

research assistant

professor

A J Hedley

chair professor

T H Lam

chair professor and

head of department

Department of

Health, Student

Health Service,

4/F Lam Tin

Polyclinic, Kowloon,

Hong Kong, China

K H Mak

consultant, community

medicine

Nuffield

Department of

Clinical Medicine,

University of

Oxford, Oxford

OX2 6HE

R Peto

professor of medical

statistics and

epidemiology

Correspondence to:

T H Lam

hrmrlth@

hkucc.hku.hk

BMJ 2005;330:287-8 
Number of subjects who were or were not exposed to secondhand smoke at home and odds ratios (adjusted for age and education, and for sex when men and women were combined) for mortality in people aged 60 or over, Hong Kong. Values are odds ratio ( $95 \%$ confidence interval) unless indicated otherwise

\begin{tabular}{|c|c|c|c|c|c|c|c|c|}
\hline \multirow[b]{3}{*}{ Cause of death } & \multicolumn{4}{|c|}{ By sex } & \multirow[b]{3}{*}{ All } & \multicolumn{3}{|c|}{ By exposure (compared with no exposure) } \\
\hline & \multicolumn{2}{|r|}{ Men } & \multicolumn{2}{|r|}{ Women } & & \multirow[b]{2}{*}{1 smoker } & \multirow[b]{2}{*}{2 or more smokers } & \multirow[b]{2}{*}{$\begin{array}{l}P \text { for } \\
\text { trend }\end{array}$} \\
\hline & $\begin{array}{l}\text { Exposed/not } \\
\text { exposed }\end{array}$ & $\begin{array}{c}\text { Odds ratio } \\
\text { (95\% CI) }\end{array}$ & $\begin{array}{l}\text { Exposed/not } \\
\text { exposed }\end{array}$ & $\begin{array}{l}\text { Odds ratio } \\
(95 \% \mathrm{CI})\end{array}$ & & & & \\
\hline \multicolumn{9}{|l|}{ Cases } \\
\hline \multicolumn{9}{|l|}{ Cancer: } \\
\hline Lung cancer & $33 / 112$ & 1.34 (0.82 to 2.17$)$ & $96 / 83$ & 1.38 (0.94 to 2.04$)$ & $1.39(1.03 \text { to } 1.88)^{*}$ & 1.30 (0.94 to 1.80$)$ & $1.74(1.06 \text { to } 2.86)^{*}$ & 0.014 \\
\hline All cancers & $166 / 685$ & 1.16 (0.85 to 1.60$)$ & $396 / 368$ & $1.35(1.03 \text { to } 1.76)^{*}$ & $1.27(1.03 \text { to } 1.55)^{*}$ & 1.14 (0.92 to 1.43 ) & $1.74(1.22 \text { to } 2.48)^{\star * *}$ & 0.003 \\
\hline \multicolumn{9}{|l|}{ Respiratory: } \\
\hline COPD & $27 / 69$ & $1.67(0.95$ to 2.94$)$ & $27 / 15$ & $2.90(1.34 \text { to } 6.29)^{\star \star}$ & $1.99(1.28 \text { to } 3.10)^{\star \star \star}$ & $1.85(1.14 \text { to } 3.00)^{*}$ & $2.51(1.22 \text { to } 5.18)^{\star}$ & 0.002 \\
\hline All respiratory & $103 / 374$ & 1.29 (0.87 to 1.92$)$ & $126 / 118$ & $1.52(1.01 \text { to } 2.27)^{\star}$ & $1.41(1.07 \text { to } 1.87)^{\star}$ & 1.31 (0.97 to 1.78) & $1.80(1.11 \text { to } 2.91)^{\star}$ & 0.007 \\
\hline \multicolumn{9}{|l|}{ Circulatory: } \\
\hline Stroke & $65 / 232$ & 1.31 (0.87 to 1.99$)$ & $158 / 142$ & $1.57(1.11 \text { to } 2.24)^{\star}$ & $1.49(1.15 \text { to } 1.94)^{* * *}$ & $1.34(1.01 \text { to } 1.79)^{*}$ & $2.08(1.33 \text { to } 3.25)^{* * *}$ & 0.001 \\
\hline IHD & $74 / 285$ & 1.30 (0.88 to 1.93$)$ & $113 / 112$ & 1.39 (0.95 to 2.04) & $1.35(1.03 \text { to } 1.76)^{*}$ & 1.26 (0.94 to 1.69$)$ & $1.68(1.05 \text { to } 2.68)^{\star}$ & 0.015 \\
\hline All circulatory & $177 / 664$ & 1.29 (0.93 to 1.79$)$ & $342 / 334$ & $1.36(1.02 \text { to } 1.81)^{\star}$ & $1.35(1.09 \text { to } 1.68)^{\star *}$ & $1.27(1.01 \text { to } 1.61)^{*}$ & $1.66(1.13 \text { to } 2.42)^{* *}$ & 0.002 \\
\hline Injury and poisoning & $14 / 63$ & $1.02(0.53$ to 1.97$)$ & $20 / 29$ & 0.81 (0.43 to 1.52) & 0.95 (0.60 to 1.49) & 1.03 (0.64 to 1.67$)$ & 0.65 (0.25 to 1.74) & 0.594 \\
\hline All causes & $552 / 2128$ & 1.25 (0.94 to 1.66$)$ & $1112 / 1046$ & $1.41(1.11 \text { to } 1.79)^{\star *}$ & $1.34(1.12 \text { to } 1.61)^{* * *}$ & $1.24(1.02 \text { to } 1.52)^{*}$ & $1.73(1.24 \text { to } 2.40)^{\star \star \star *}$ & $<0.001$ \\
\hline Controls & $71 / 347$ & & 150/195 & & & & & \\
\hline
\end{tabular}

$\mathrm{COPD}=$ chronic obstructive pulmonary disease; $\mathrm{IHD}=$ ischaemic heart disease.

${ }^{*} \mathrm{P}<0.05,{ }^{*} \mathrm{P}<0.01,{ }^{* \star *} \mathrm{P}<0.005$ on logistic regression.

reliably recorded ${ }^{2}$ and is a good proxy for social class in Hong Kong. As data on cases and controls were derived from the same proxy, reporting bias should be minimal. ${ }^{2}$ If our results are not due to residual confounding, they provide further evidence that the dose-response associations between passive smoking and stroke and all cause mortality are likely to be causal.

We thank W L Cheung for help with analysis; the Immigration Department of the Government of the Hong Kong Special Administrative Region for data and assistance; and, in particular, the relatives who provided information.

Contributors: THL, SYH, AJH, KHM, and RP designed and carried out the study on which this analysis was based; $\mathrm{SMcG}$, MS, LMH, and GNT planned and carried out this analysis; and all authors contributed to writing the paper. SMcG and THL are guarantors.

Funding: Hong Kong Health Services Research Committee (\#631012) and Hong Kong Council on Smoking and Health.
Competing interests: THL is vice chairman and $\mathrm{AJH}$ a former chairman of the Hong Kong Council on Smoking and Health.

Ethical approval: Ethics Committee of the Faculty of Medicine, University of Hong Kong.

1 Hill SE, Blakely TA, Kawachi I, Woodward A. Mortality among never smokers living with smokers: two cohort studies, 1981-4 and 1996-9. BMJ 2004;328: 988-9.

2 Lam TH, Ho SY, Hedley AJ, Mak KH, Peto R. Mortality and smoking in Hong Kong: case-control study of all adult deaths in 1998. BMJ 2001;323:361-2

3 Bonita R, Duncan J, Truelson T, Jackson RT, Beaglehole R. Passive smoking as well as active smoking increases the risk of acute stroke. Tobacco Control 1999;8:156-60.

4 Iribarren C, Darbinian J, Klatsky AL, Friedman GD. Cohort study of exposure to environmental tobacco smoke and risk of first ischemic stroke and transient ischemic attack. Neuroepidemiology 2004;23:38-44.

5 Kay R, Woo J, Kreel L, Wong HY, Teoh R, Nicholls MG. Stroke subtypes among Chinese living in Hong Kong: the Shatin stroke registry. Neurlogy 1992:42:985-7. (Accepted 12 August 2004)

doi 10.1136/bmj.38342.706748.47

\section{$Q \mathcal{E} A$}

\section{Women's experiences of breast and ovarian cancer}

\section{Question}

Where can I read how other women responded when they were diagnosed as having breast and ovarian cancer?

T Scarlett Epstein, director and development economist, PEGS, 5 Viceroy Lodge, Hove

\section{Answer}

ACOR (Association of Cancer On Line Resources) is an excellent online group at www.acor.org. It is primarily comprised of survivors and care givers, but medical professionals also contribute. It lists over 100 disease sites, and I would recommend the Ovarian Cancer Problems Discussion Group as there are several women with dual primaries or genetically predisposed because of BRCA1 or BRCA2.

Sandi Pniauskas, ovarian cancer survivor and advocate

\section{Answer}

I strongly recommend the DIPEx website which (according to the home page) "was created by Dr Ann
McPherson CBE and Dr Andrew Herxheimer after their own experiences of illness. Ann had been diagnosed with breast cancer and although she knew all the medical information, couldn't find anyone else to talk to about what it was really like to have the disease." It's a fascinating collection of narratives.

There's no section on ovarian cancer yet, but a large section about breast cancer at www.dipex.org/Issues/ ?ILLNESS $=$ bca

Theo H Fenton, consultant paediatrician, Mayday Hospital, Croydon

http://bmj.bmjjournals.com/cgi/qa-display/short/ bmj_el; 49860

This exchange was posted on the QEA A section of bmj.com.If you want to respond to the question, or ask a new question of your own, follow the link above or go to http://bmj.com/q\&a 